\title{
The "I" in BRICS: leadership traits of Indian prime ministers and India's role adaptation to rising status in world politics
}

\section{Barış Kesgin $^{1}\left[\right.$ - Leslie E. Wehner ${ }^{2}(\mathbb{C}$}

Published online: 20 September 2021

(c) Springer Nature Limited 2021

\begin{abstract}
This paper inquires theoretically into how leaders act and react to the state role of rising power through the case study of India. It brings together role theory and leadership trait analysis, and contends that there is a puzzling interplay between rising status and leaders' characteristics. We project that leaders' traits and styles condition how they enact roles. India and its leaders offer a suitable case for investigating this issue. Since the economically unstable early 1990s, India has gone through a relatively successful era of global emergence. Thus, we examine the relationship between India's roles and the leadership profiles of Prime Ministers Atal Vajpayee, Manmohan Singh and Narenda Modi, specifically their belief in the ability to control events and the need for power. We find especially in Vajpayee and Singh that their traits can help explain India's foreign policy roles and in Modi (first term only) a leader vulnerable to contextual winds. We argue that the interplay of leaders' traits and roles, as expressions of both material and social dimensions, helps assess how they make sense of their country's rising within both the regional and international systems.
\end{abstract}

Keywords Emerging power role $\cdot$ Foreign policy $\cdot$ India $\cdot$ Leadership trait analysis Leaders $\cdot$ Role theory

Leslie E. Wehner

1.e.wehner@bath.ac.uk

Barış Kesgin

bkesgin@elon.edu

1 Elon University, Elon, NC, USA

2 University of Bath, Bath, UK 


\section{Introduction}

The study of emerging powers in world politics has received broad policy and academic interest in recent decades, yet this research has hitherto been approached mainly from a systemic perspective (Ebert and Flemes 2018; Larson 2018; Stuenkel 2016; Thies and Nieman 2017). This inquiry tends to focus on possible systemic consequences for the current world order, and for the position of the United States as global hegemon (see Paul 2016; Thies and Nieman 2017). However, leaders from emerging powers show different patterns of behaviour about the rising process their respective states experience. Brazil's change of leadership from Cardoso (1995-2002) to Lula da Silva (2003-2010) implied a shift to how its rising power role was to be played. Cardoso gave priority to a closer relationship with great powers such as the US and European states while Lula da Silva focused more on SouthSouth coalitions (Cason and Power 2009). South Africa adopted the status of emerging power, but this role has been enacted in distinct ways by its leaders since the 1990s. In fact, van der Westhuizen (2016) detects strong variation on foreign policy positions of South African leaders. Presidents Mandela, Mbeki and Zuma differed in their emphases between the African continent and Western powers, and on key policy issues such as regional institutions and crisis, and global governance matters. These few examples show that the styles leaders bring to foreign policy are key to understanding how rising is being advanced by emerging powers. When focusing on rising strategies, there is a priori not much variation to be seen since most studies on emerging powers adopt a systemic approach and a so-called long term national interest perspective, which masks the variation that leadership styles can bring to the rising process of a state as part of its foreign policy (Wehner 2017).

This paper pursues this missing link in studying rising powers from an individual level of analysis with a role theory lens because individuals' agency has been neglected in the study of emerging powers (Wehner 2017). We focus on leaders' traits as the causal force behind how the rising power role of the state is being played. This interplay between leaders and their country's rising status is also a key foundation for future research. Thus, the goals of this paper are twofold. First, it aims at providing a theoretical and methodological way to study how leaders affect their states' rising power role. How does a leader shape foreign policy of an emerging power? Do leaders respond to rising power role in similar ways or pursue policies with different tones? We answer these questions by bringing in one of the established approaches to studying political leaders-leadership trait analysis (LTA) - to role theory research in foreign policy. Second, the paper advances empirical analyses based on the personality profiles of India's three most recent prime ministers: Atal Vajpayee (1998-2004), Manmohan Singh (2004-2014), and Narendra Modi (2014-present). ${ }^{1}$ Similar to a lack of attention to the individuals in the broader

\footnotetext{
1 While Modi remains India's prime minister, this paper concerns his first term only.
} 
literature (Wehner 2017), these figures are curiously understudied -especially from a rising power perspective. ${ }^{2}$

Our premise is that rising or emerging power is a role that implies significant modifications to a state's status in world politics-a rearrangement of various constraints it deals with. Then, we contend, political leaders interpret such changes and shape foreign policy roles in different ways. We show that it is leaders' personality characteristics that affect, shape, and make sense of how the emerging power role is enacted and played. That is, the causal force behind the emerging power role is the leader's perceptions of the existing systemic constraints. Whether a leader respects or challenges constraints is key to their understanding of the nuances and adjustments of how the emerging power role and auxiliary role functions will be played in world politics. We argue that emerging powers' leaders will pursue policies as they deem fit to their state's roles in international politics but will do differently due to their own notions of systemic constraints. We tackle this assumption with Hermann's (2003) LTA and with role theory because roles are the expression and the outcome both of agents and systemic conditions (Thies 2013; Walker 1987). LTA is an at-a-distance approach to studying political elites that captures their responsiveness to constraints through a leader's belief in their ability to control events and need for power, and how these traits influence (or not) the leader's orientation towards world politics. Role theory, in turn, represents a fruitful nexus between status and different role functions that a state plays to underpin its aspired-to or indeed achieved status (Thies 2012; Wehner 2015). This approach helps bring together the study of leaders' personalities and role theory research in the context of a state's rising power status, and therefore establish how leaders shape rising in their foreign policy orientations.

India offers a suitable context for inquiring into this interplay between individual-level variables such as personality traits and processes of structural social rising within world politics. This goes beyond the fact that India's prime ministers have hitherto been its primary policymakers (e.g. Mitchell 2007: 252). After traditionally being recognised as a nonaligned state during the Cold War, India faced an uncertain future with its end. Then, it reoriented its foreign policy, became more active in multilateral institutions, and slowly adopted the rules of economic globalisation. Concurrently, India focused on achieving a status of newly industrialising state. India took a more generous approach to its neighbours in the 1990s (Gupta et al. 2019; Malone et al. 2015). Moreover, it developed nuclear capabilities to cope with neighbouring Pakistan's own nuclear ambitions (Sinha 2016). Later, India also staked its claim to a permanent seat in the United Nations Security Council (UNSC)—while the US considered it a balancer to China's rise in South Asia (Thies and Nieman 2017). Most importantly, India enjoyed acceptance by the audience of states as an emerging power in world politics and has become a key actor within the BRICS club.

\footnotetext{
2 An exception is Mitchell (2007), yet he does not focus on the interplay between rising power status and leaders' personalities. Mitchell's paper includes a profile of Vajpayee, along with Jawaharlal Nehru, Indira Gandhi, and Rahul Gandhi.
} 
Personal, national and systemic factors drive India's foreign policy (Ganguly 2010). Political leaders leave their mark on the type of roles India plays regionally and internationally. Ganguly (2010) proposes that with the exception of the left in Indian politics, a consensus emerged within the political elite about the need to pursue a pragmatic foreign policy that would potentiate India's material capacities and increase its global standing. This demonstrates an awareness of India's elites about the country's own rising process within world politics. However, an individual-based approach to rising powers and India has not unpacked specifically the influence of leaders and their leadership styles on their country's foreign policy under conditions of rising (Wehner 2017). ${ }^{3}$ In fact, leadership styles have been broadly documented as a source of influence, direction, and redirection in foreign policy (e.g. Cuhadar et al. 2017b, 2021; Dyson 2006; Hermann 2003; Kesgin 2019).

The remainder of this paper proceeds as follows. First, we concentrate on the different aspects, dimensions, and theorisations of the phenomenon of rising powers. Second, we introduce our framework for this study of the interplay between leaders and roles. Third, we describe the different roles that India plays in international politics. Fourth, we analyse the aforementioned prime ministers' personality traits. Finally, we discuss India's foreign policy given our findings and their theoretical and empirical implications for a future research agenda on emerging powers' foreign policies.

\section{Rising powers in foreign policy}

Research on emerging powers often focuses on the systemic consequences of new powers rising to global prominence, and on whether or not the US will lose its predominant position in the future. Power transition theory predicts that new powers' ambitions will disrupt the current world order. The even distribution of material capabilities between actors will lead to conflict as they come to enjoy relative power parity (Organski and Kugler 1980). Lemke (2010), for instance, studies regional powers from this perspective, and concludes that power parity within a region will increase conflict between challengers and a regional power. Conversely, he argues that if a regional power predominates in its region, then this material superiority will deter others from challenging it. Likewise, Mearsheimer (2014) deduces that the rise of new powers is rarely a peaceful process. In fact, he argues that China-as the most powerful of the contemporary rising powers-will eventually challenge the US's hegemonic position.

In contrast, Thies and Nieman (2017) use structural variables (such as competition and socialisation) and ideational variables (such as national role conceptions) to study BRICS's impact on the international system. They conclude that the rise of BRICS will not necessarily lead to conflict in their quest to a higher status as great powers. The study of these eventual systemic consequences also involves institutionalism, as it focuses on how and the extent to which emerging powers

\footnotetext{
${ }_{3}^{3}$ One exception is He and Feng (2015).
} 
contest the existing architecture of global governance (Cooper 2016). Hurrell (2008) mentions that emerging powers are seeking to reform the current multilateral system rather than transform it substantially. Others argue regional powers want a 'fairer' representation of their self-perceived new status in the multilateral system (Alexandroff and Cooper 2010; Stuenkel 2016). Notably, any considerations of how individual leaders may differ in their interpretations is absent from these conversations (Wehner 2017).

In their quest for better representation within multilateral institutions, emerging powers perceive themselves as acquiring or being entitled to a new status position. In fact, emerging powers unfold foreign policy strategies to cast and achieve this new status: BRICS, for example, have demonstrated creative statusseeking strategies, which manifest in major diplomatic initiatives or in foreign policy activism. For instance, India contributed to the policing of the Indian Ocean to control piracy (Larson and Shevchenko 2014: 46-48). Similarly, India attempted to increase its soft power in Africa: its involvement in Nepal to promote peace and democracy illustrates such attempts (Destradi 2012).

While status concerns are key aspects of rising powers' foreign policies, relevant research also displays an exclusive focus on systemic or state level of analysis-thus, leaving aside individuals (Volgy et al. 2011). Destradi (2017) identifies that the existing research talks about reluctant regional powers or emerging powers. Arguably, the 'reluctant' part emanates from domestic-level constraints that these actors experience in pursuing or achieving a particular foreign policy agenda. At this domestic level, the views and personalities of leaders are key to understanding emerging powers' patterns of behaviour and quests for status. However, this individual level of analysis has been neglected by scholars in the emerging powers research agenda at the expense of identifiable systemic concerns. In this sense, the extent to which individuals make a difference in how the rising power role unfolds is key to understanding whether a state will adopt a cooperative or conflictual approach to rising. Thus, we propose, it is leaders that make sense of how a rising process is advanced through patterns of conflict or cooperation in their states' foreign policies.

The vast literature on India as a rising regional power replicates the systemic emphasis mentioned earlier. Sinha (2016) studies how India is being accommodated and is self-accommodating in the regional and international systems (see also Paul and Shankar 2014). Thies and Nieman (2017) focus on the systemic effects of the rise of India and the rest of BRICS, while others provide an analysis of India's approach to international negotiations (Narlikar and Narlikar 2014). Destradi (2012) examines India's foreign and security policy strategy in South Asia by using the analytical categories of 'imperialist', 'hegemonic', and 'leadership' strategies. Others concentrate on regional peer contestation to the leadership role of India-something that is seen as hampering its rising process (Blarel and Ebert 2015; Ganguly 2018a, b), and India's major power and regional roles (Ganguly 2010). While some studies of India's regional actions or inactions incorporated domestic and subnational variables (Destradi 2012; Friedrichs 2019; Plagemann and Destradi 2015), a focus on Indian prime ministers is rather absent in the scholarship on India's rising (see Guha 2010: 289). 
Most of the research on emerging powers and on India's rising adopts a structural outlook that asks whether rising powers will challenge great powers, the current international order, or will they rather pursue a foreign policy of accommodation into the current international order. While structure predominates in the study of rising powers, the state as unit of analysis is often blackboxed. Here, the existing systemic concerns are the reasons to focus on how leadership styles inform the rising power status since it is leaders who read and navigate through international systemic constraints. Accordingly, this article brings together the systemic and individual level of analysis through the case of India's emerging process.

\section{Role theory and leadership trait analysis}

\section{Roles in symbolic interactionism}

Roles are expressions of the existing properties of both agents and structures; as an approach, roles can tie together structural international relations and agency driven foreign policy approaches (Breuning 2011; Thies and Nieman 2017). Roles are social positions within an organised group and the type of actor is possible to be in society (Harnisch 2011; Thies 2010). Roles are socially constructed through a constant interaction between Ego (Self) and Alter (Other). The interaction between Ego and Alter takes form in a role for the self and a counter-role for the other (Wehner and Thies 2014). Role conception involves the self-definition of a role as much as the expectations that others hold about an actor. Role location refers to the process in which the self locates a role within a social structure and the other accepts such a role in a role-counter-role interaction (Thies 2010). Role location can be seen as the actual manifestation of how foreign policy is conducted. Hence, the role location is the actual foreign policy behaviour of the state which is role-based (Thies 2012; Walker 1979: 177). Role play is the actual performance of a role once a role has been chosen or located within a social structure (Thies 2010).

While an actor possesses a role set, not all roles mean the same thing. Certain roles are performed on a daily basis, others only sporadically-depending on the context, and how central that role is to an actor's identity. ${ }^{4}$ Hence, there is a hierarchy of roles for an actor. In fact, states have a master role- the most salient attribute of an actor-and rely on a set of auxiliary roles that underpin it (Thies 2012). A master role needs to be socially articulated and validated in the role location process. Master roles require material sources, which are the bottom line for a state to hold a specific master role as regional or great power (de Sá Guimares and Maitino 2017; Thies 2013; Wehner 2015).

We use master role as synonymous with status position, as advanced by Thies (2012, 2013; see also Wehner 2015). The emerging power role is both self-conceived and attributed by others, and is indicative of certain qualities such as growing

\footnotetext{
${ }^{4}$ On the difference between identity and roles see Wehner and Thies (2014); see also Breuning (2011), Harnisch (2011), and McCourt (2014).
} 
materially and achieving influence in regional and international affairs. The emerging power role is a social category that also shows a new status position even if this is transitory to achieve a desired status or role as great power (Thies and Nieman 2017: 31). Emerging power in role theory language becomes the most salient social category for the state to be identified by other state actors; hence, it becomes a master role (Breuning and Pechenina 2020; de Sá Guimares and Maitino 2017; Thies 2013; Wehner 2015). Master roles and their eventual realisation are underpinned by and subject to the type of auxiliary roles that states play, such as leader, mediator, security provider, developer, and nuclear power. Auxiliary roles are the active components of a master role and are sources of action in specific social contexts and foreign policy matters (Breuning and Pechenina 2020; Thies 2012; Wehner 2015). The growing capabilities of a rising power will make possible this actor to locate and achieve more auxiliary roles than in a previous status position as minor members of the system or just as regional powers. Emerging powers are most likely regional powers too (Thies and Nieman 2017: 28-34).

While systemic and external forces affect a state's master role location, domestic factors too influence the role play of a master role. Here, political leadership is important-when a state has or is aspiring to a master role, then leaders have to navigate domestic contestations to both master and auxiliary roles (Cantir and Kaarbo 2012). When leaders make a decision following domestic deliberations, they not only implement the selected role but also influence how that role is being played. Leaders' characteristics matter, because leaders act as key force to interpret how the state's roles should be played (Wehner and Thies 2021). Moreover, leaders have specific traits that can help elucidate why achieved and prescribed roles associated with a given status are performed vis-à-vis a state's own capabilities. The role enactment process (meaning how a leader executes a role), then, is a neglected dimension of studying emerging powers in their quest for acquiring status as they rise. Leaders are important since it is they who primarily shape and can even transform the most of the state's structural and social process of rising as international actors. Leaders shape and affect how the emerging power role is advanced, and select which auxiliary role that underpins the master role will be enacted. These auxiliary roles become meaningful to sustain the master role of emerging power when leaders face specific and particular regional and international settings and role demands (see Breuning and Pechenina 2020; Thies 2013; Thies and Nieman 2017; Wehner 2015). We argue, then, for connecting role theory with the systematic study of these political leaders. 5

${ }^{5}$ For a similar undertaking (i.e. connecting systemic and individual levels), see Walker et al. (2016). 
Table 1 Personality characteristics in leadership trait analysis

\begin{tabular}{ll}
\hline Trait & Description \\
\hline Belief in ability to control events & Perception of own degree of control over political world \\
Need for power & Interest in developing, preserving, or reinstituting own power \\
Conceptual complexity & Ability to distinguish complexities of political life \\
Self-confidence & Notion of self-importance, and of his/her capacity to take on \\
& the political environment. \\
In-group bias & Belief that own group constitutes the center of political world \\
Distrust of others & Suspicions, skepticism, worry of others than own group \\
Task focus & Concentration on problem solving vs. building relationships \\
\hline
\end{tabular}

Source Cuhadar et al. (2017a), originally adapted from Hermann (2003)

\section{Leadership trait analysis (LTA)}

The study of elites in foreign policy offers different approaches and tools for this undertaking (Post 2003). ${ }^{6}$ Hermann's (2003) LTA is one of the most suitable to develop personality profiles of rising powers' political leaders. Many scholars have successfully applied LTA in a variety of political contexts (e.g. Cuhadar et al. 2021; Dyson 2006; Hermann 1987; Kesgin 2019, 2020; Kille and Scully 2003). According to LTA, political personality is a combination of seven traits: belief in the ability to control events, conceptual complexity, the need for power, distrust of others, in-group bias; self-confidence, and task orientation. LTA utilises a content analysis scheme to calculate numerical scores between 0 and 1 for each trait; a higher value indicates that the leader exhibits the trait in question more saliently. These scores gain explanatory power in comparing the leader's scores to those of a control group. Table 1 briefly summarises each trait.

Hermann also articulates leadership styles based on these LTA profiles. Each style in turn describes how 'leaders relate to those around them and how they structure interactions and the norms, rules, and principles they use to guide such interactions' (Hermann 2003: 181). Table 2 succinctly presents these combinations of leadership traits. ${ }^{7}$

When a state ascends to an emerging power role in world politics, the systemic expectation is that leaders of a rising state will tend to challenge international constraints. Yet, from a personality approach such as LTA, this assumption cannot be

\footnotetext{
${ }^{6}$ LTA offers the most fitting framework for our purposes on leaders and systemic constraints. Another well-established approach to profiling leaders, operational code analysis (Schafer and Walker 2006) would similarly help explore the interplay between rising powers' elites and roles (see Wehner and Thies 2021). Operational codes capture leaders' beliefs and may assist in answering other questions. For instance, do rising powers' leaders perceive the world more friendly or confrontational?

7 While we do not explore this here, one can well expect other associations between personality traits and rising power status. The various combinations of these traits can also offer further insights into emerging powers' leaders and how they perceive their current master roles, auxiliary functions, and any role change. There remain multiple opportunities to pursue similar research endeavours (Wehner and Thies 2021).
} 


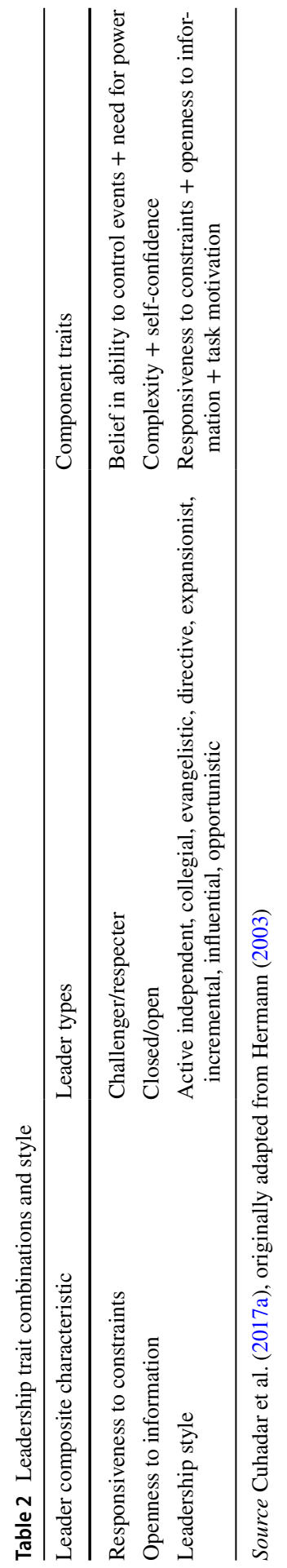

s. 
Table 3 Leaders' responsiveness to constraints and behavioral expectations

\begin{tabular}{lll}
\hline Need for power & Belief in one's own ability to control events & High \\
\cline { 2 - 3 } Low & $\begin{array}{c}\text { Respect constraints; work within such } \\
\text { parameters toward goals; compromise } \\
\text { and consensus building important }\end{array}$ & $\begin{array}{c}\text { Challenge constraints but less } \\
\text { successful in doing so because } \\
\text { too direct and open in use of } \\
\text { power; less able to read how } \\
\text { to manipulate people and set- } \\
\text { ting behind the scenes to have } \\
\text { High }\end{array}$ \\
$\begin{array}{c}\text { Challenge constraints but more comfort- } \\
\text { able doing so in an indirect fashion- } \\
\text { behind the scenes; good at being "power } \\
\text { behind the throne" where they can pull } \\
\text { strings but are less accountable for result }\end{array}$ & $\begin{array}{c}\text { Challenge constraints; are skillful } \\
\text { in both direct and indirect influ- } \\
\text { ence; know what they want and } \\
\text { take charge to see it happens }\end{array}$ \\
\hline
\end{tabular}

Source Hermann (2003: 188)

taken for granted. According to LTA, the leader's belief in his/her ability to control events and their need for power indicate how they react to constraints in terms of challenging or respecting them (Hermann 2003). We predict that an emerging power's foreign policy behaviour will be conditioned by these two traits of its leaders' and their responsiveness to constraints in world politics. As we elaborate further in the following section, we hypothesise that leaders of an emerging power will exhibit differences among each other. LTA, precisely, projects that based on leader's belief in their ability to control events and the need for power traits, this would vary. According to Hermann (2003), when both the belief in the ability to control events and the need for power scores traits are high, a leader is expected to challenge constraints. It is noteworthy that a high need for power has been associated with competitiveness and aggressiveness (Hermann 2003). Otherwise, any combinations of high and low in these two traits suggest leaders would again challenge constraints. When either the belief in the ability to control events or the need for power is high, one may conclude that leaders will pursue an assertive foreign policy agenda (Hermann 2003). Indeed, the single combination of these two traits that Hermann projects as constraint respecters is when both traits are low. Table 3 summarises these expectations.

Leaders' responsiveness to constraints already emerged as an important contextual element in international relations (Cuhadar et al. 2017b; Dyson 2006; Hagan 1994; Keller 2005). Constraints can take various forms, however; while some focused on domestic political constraints (Dyson 2006; Keller 2005), few others considered systemic constraints (Cuhadar et al. 2017b). Keller (2005) found that democratic leaders challenging constraints are likely to use force in a crisis. Dyson (2006) attributed Britain's different policies in Vietnam and Iraq to the respective British prime minister's approach towards constraints. Cuhadar et al. (2017b), on the other hand, investigated how two Turkish leaders responded to comparable events (the 1991 and 2003 Iraq wars) under similar systemic constraints. Obviously, leaders may not necessarily fit into constraint respecter or challenger category in every 
single instance as they are ideal-type categories, but these indicate overall patterns and tendencies of the leader. At the same time, leaders that are either constraint respecters or challengers will under certain conditions still challenge or respect constraints whenever deemed necessary (Keller 2005: 840). While we assume-like Keller - that these two categories are overall indicative of tendencies, we are interested in how leaders react to international systemic constraints following Hermann (2003).

\section{The interplay between roles and LTA}

The influence of a leader's personality and how it shapes the performance of a state role under conditions of rising promises a fruitful research venture in an alliance between role theory and LTA (Wehner and Thies 2021). Role theory's construct as a multilevel approach is based on its organisational value. This ability to cross different levels of analysis implies that roles are expressions of a social structure that facilitates or constrains the enactment of certain roles. However, the agency capacity of individuals (and corporate actors, such as the state) is key to the constitution and formation of roles -as is the social context in which the actor is located in (Breuning 2011; McCourt 2014; Thies 2010; Thies and Nieman 2017; Wehner and Thies 2014). Thus, the individual has the freedom and creativity to give an existing role their own imprint or to create a new role performance on his/her own (Wehner and Thies 2021). This process, known as 'role-making', is about how the actor innovates and creates their own role by still following the demands from other social actors to locate a role that is appropriate to a particular social context (McCourt 2014). In other words, roles as performed by individuals are both influenced by the social environment as much as the individual-who has their own creative ways to perform roles within, and to navigate through, such social structures (Goffman 1971).

Likewise, individuals when taking on (role-taking) organisational roles such as the one of president or prime minister follow the ground rules of this position, or what is expected from them as leaders. However, these leaders are still able to perform the roles according to their own individual traits and styles. Both leadership traits and styles are the elements that enable leaders to decide to continue with an inherited role play from their predecessors without much adjustment, or to create and innovate an altogether new script and role performance (see Wehner and Thies 2021; see also Hollis and Smith 1986; Marsh and Jones 2017). ${ }^{8}$ Consequently, leaders as foreign policy actors experience a similar process to the one described previously - that is, when assuming the demands of the post of president or prime minister, as a type of organisational role. It is leaders as agents that select, interpret and perform a role on behalf of the state, possibly one that has hitherto been a stable part of a state's role fabric in foreign policy.

In fact, Holsti (1970) looks at policymakers' speeches and discourses to establish the different roles that a state can conceive in the international system. These

\footnotetext{
${ }^{8}$ Hollis and Smith (1986) refer to the process of role distance as key for the leader to be able to judge and interpret the roles of the state and thus bring their own ways of playing such set of roles.
}

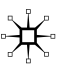


policymakers are presidents, prime ministers, foreign ministers, that is, the individuals to whom Holsti attributes the capacity to speak on behalf of the state (see Wehner and Thies 2021). Hence, the location of new roles in a social structure (Thies 2012), or the variation on how the existing state roles are to be performed, also depends on the traits of the leaders of that state (Wehner and Thies 2021). Leaders when exposed to a social environment can either respect or challenge the constraints that arise from within the system in the form of social cues ('general other'), or directly from other actors that are significant to locate a role relationship ('significant other') (Harnisch 2011). Thus, not only are the international structure and agency of the state as corporate actor key to the process of role play, as are domestic institutions too, but above all it is individuals in power who take supreme importance-as they can either follow an existing role, adjust it, or change it altogether.

It is this interplay, envisioned by Holsti (1970) and others, between leader and role that brings us to marry role theory and LTA. The latter is an appropriate methodological toolkit to understand and unpack the key personality traits accounting for how roles are played, adjusted, and even transformed (Wehner and Thies 2021), as a state and its leaders confront systemic conditions of rising within the international system. This choice is similarly important when adopting rising power as master role that is not only the expression of structural forces of the system, but also of the agency of key agents in the foreign policy process as leaders are. When emerging power is considered a role on its own, then it has action in its core and as such the key force behind this master role as we expect are leaders in power. LTA provides two traits that can be related to structural features and how leaders read and make sense of them. A leader's belief in their ability to control events and their need for power indicate how they respond to constraints; for our interests, a leader has to navigate through regional and international power constellations when performing the role of emerging power. These two traits-as capturing the dynamic process of how structures are perceived by agents — can shed light on the debate over the consequences of rising powers in the international system that have the problem of being overtly structural. Whether emerging powers will pursue more assertive, proactive, independent and even more aggressive foreign policies regionally or internationally towards great powers or regional peers and neighbours originates from how leaders see constraints (i.e. surmountable or not) is key to understanding the foreign policy of emerging states. Thus, bringing together LTA and roles in general and how these two traits in particular can be associated with structural features from an agency perspective will illuminate the type of rising emerging powers that leaders pursue.

Our expectations are first-cut propositions that help us to narrow down the empirical analysis. Thus, a constraint respecting leader will play the master role of rising power in a more consensus-based manner and will often pursue a more dependent foreign policy on important powers that are seen as allies and rivals in the region and abroad. At the same time, such leaders will play the emerging power role through a passive and rather reactive foreign policy in its region and towards great powers. Rather than managing the foreign policy constraints, a constraint respecting leader will be more focused on the reactions of others states to India's own foreign policy initiatives. In contrast, a constraint challenging leader will play the rising power role in a more confrontational, unilateral, and independent way vis-à-vis regional peers 
Table 4 LTA scores of India's Prime Ministers

\begin{tabular}{lllll}
\hline & Vajpayee & Singh & Modi & $\begin{array}{l}\text { World mean } \\
\text { (standard devia- } \\
\text { tion) }\end{array}$ \\
\hline Belief in ability to control events & .324 & .268 & .344 & $.35(.05)$ \\
Conceptual complexity & .600 & .650 & .598 & $.59(.06)$ \\
Distrust of others & .225 & .105 & .068 & $.13(.06)$ \\
In-group bias & .208 & .189 & .139 & $.15(.05)$ \\
Need for power & .335 & .275 & .259 & $.26(.05)$ \\
Self-confidence & .348 & .433 & .359 & $.36(.10)$ \\
Task focus & .582 & .588 & .640 & $.63(.07)$ \\
$N$ & 28 & 35 & 14 & 284 \\
\# of words & 25,403 & 43,171 & 21,531 & n/a \\
\hline
\end{tabular}

and great powers. Moreover, a constraint challenging leader will play the emerging power role when possible in a more assertive and proactive manner by providing options to other states in a rather 'take it or leave it' way.

\section{Research design}

We collected the spontaneous foreign policy remarks of India's three most recent prime ministers' (Vajpayee, Singh and Modi) during each one's tenure. ${ }^{9}$ Leaders' statements originate from either interview or press conference settings where they responded to questions from members of the media. In selecting these spontaneous foreign policy utterances, this study adopts Hermann's principle that they offer the most unfiltered access to leaders. We obtained the remarks from the webpages of the Indian Ministry for External Affairs and (for Modi, in particular) of the Prime Minister's Office. ${ }^{10}$ Electronic databases such as LexisNexis, Factiva, and Foreign Broadcasting and Information System, and news organisations' webpages supplemented our transcripts in a few instances. All texts were already translated into English, or sometimes the leader already spoke in that language. ${ }^{11}$ For LTA, a response/ record of at least one hundred words is expected to produce a meaningful result; an accurate LTA profile requires at least 5000 words being analysed. Any quotations

\footnotetext{
9 Vajpayee was in office from 19 March, 1998, to 22 May, 2004, followed by Singh, who remained prime minister until 26 May, 2014. Modi has been India's prime minister since then, and was reelected in May 2019. Since the elections, there is a dearth of foreign policy relevant interviews that Modi has given; since covid-19 engulfed the world, Modi has not given many foreign policy interviews. We kept our analyses confined to Modi's first term.

${ }_{10}$ We also cross-checked Modi's personal webpage for his listed interviews therein.

11 We acknowledge - and welcome - new developments in coding capabilities in languages other than English (see Brummer et al. 2020). We also accept earlier findings that translations do not cloud profiling (Hermann 1987). Relatedly, Windsor et al. (2019) find that the effect size of translations on original documents is small 'especially when looking at psychological processes'.
} 
of the Indian prime ministers in this paper do not overlap with the material that we used for developing their personality profiles. To calculate leadership traits scores, we used ProfilerPlus (version 5.8.4) developed by Social Science Automation (Levine and Young 2014).

\section{Personality traits of India's prime ministers}

Our findings, Table 4 below, show that the personality traits of India's three most recent prime ministers differ from one another. ${ }^{12}$ To provide background to our discussion, we first summarise our findings_-with each leader's traits compared to world leaders' average scores. To start with, Vajpayee's belief in his ability to control events leans low, and his need for power is more than one standard deviation higher than the world leaders' average. These suggest Vajpayee would challenge constraints in an indirect manner. Vajpayee is distrustful of others and has a high in-group bias - in both traits, he is one standard deviation higher than the world leaders' average. Such leaders 'focus on eliminating potential threats and problems' (Hermann 2003). Vajpayee's complexity and self-confidence are both near the average; a numerically higher complexity score would seem to indicate his openness to new information. Vajpayee has a lower task focus average, which suggests his orientation toward relationships rather than problem-solving. These together point to a directive style of leadership, where leaders focus on 'maintaining one's own and the government's status and acceptance by others by engaging in actions on the world stage that enhance the state's reputation' (ibid.).

Singh, relative to Vajpayee and Modi, deviates the most from the world leaders' average scores. He has a low belief in his ability to control events, more than one standard deviation below the world leaders' average. His need for power is near the average. Singh would either respect or challenge constraints. Singh's distrust is slightly below the average and leans low, while his in-group bias is well above the average and leans high. Accordingly, Singh would 'focus on dealing with threats and solving problems' (ibid.). Singh has high complexity and self-confidence scores, which indicates he would be open to new information. Finally, Singh's task focus score suggests that he has a relationship orientation. Sing would have a directive or collegial leadership style; when challenging constraints, he would 'focus on maintaining [his] own and the government's status and acceptance by others' (ibid.). When respecting constraints, as a collegial leader, Singh would concentrate on 'reconciling differences and building consensus' (ibid.).

Modi's traits are all near world leaders' averages; where he differs noticeably is his distrust of others. Modi's distrust is one standard deviation lower than the world

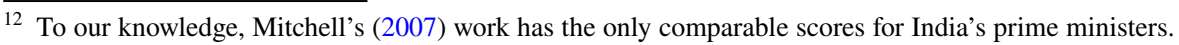
Unlike our results, Mitchell found a 'high degree of similarity between the four prime ministers [Nehru, Indira and Rajiv Gandhi, and Vajpayee]' (Mitchell 2007: 256). For Mitchell, leadership styles are of primary interest; and, he notably finds more similarities among the four prime ministers than differences. While we do not contest the significance of leadership styles, here we first look at two key traits.
} 
Table 5 India's other auxiliary roles

\begin{tabular}{|c|c|}
\hline Auxiliary role & Behavioral expectations \\
\hline Non-aligned & $\begin{array}{l}\text { Not take sides between blocs or states in particular in both ideological and } \\
\text { security disputes; if necessary, can actively get involved in bringing together } \\
\text { opposing sides }\end{array}$ \\
\hline Balancer & $\begin{array}{l}\text { Adopt strategies and tactics that oscillate between hard and soft balancing to } \\
\text { extra-regional powers or other possible regional competitors }\end{array}$ \\
\hline Bridge-builder & $\begin{array}{l}\text { Prevent great powers' dominance or any possible (regional) competitor in } \\
\text { achieving predominance; adopt strategies and tactics that oscillate between } \\
\text { hard and soft balancing to extra-regional powers or other possible regional } \\
\text { competitors }\end{array}$ \\
\hline Nuclear power & $\begin{array}{l}\text { Use nuclear capacity to deter other actors and to reduce existing regional and } \\
\text { extra-regional threats, or to target rivals and threats }\end{array}$ \\
\hline Regional peacekeeper & $\begin{array}{l}\text { Actively engage and participate in military or civilian programs provision of } \\
\text { peace support under the umbrella of the UN or regional groupings }\end{array}$ \\
\hline Democracy promoter & Actively engage in activities and programs to diffuse democratic values \\
\hline Liberal example & $\begin{array}{l}\text { Adopt a set of liberal values such as democracy and internal development pro- } \\
\text { grams that others' states in that social setting validate and may tend to emulate }\end{array}$ \\
\hline Developer & $\begin{array}{l}\text { Create and implement aid programs and economic policies to support less } \\
\text { developed states }\end{array}$ \\
\hline
\end{tabular}

Sources Holsti (1970), Hansel and Möller (2015), Thies and Nieman (2017)

leaders' average. This outcome makes it difficult to assess the current prime minister's profile, because one may expect Modi to differ from other leaders in either direction. This profile would suggest that Modi 'will generally respect constraints but under certain circumstances can challenge what appear to be inappropriate or unfounded limitations on his role' (ibid.: 316$).{ }^{13}$

\section{Leaders and roles: leadership traits of India's foreign policy}

Each Indian prime minister shapes and affects the emerging power master and associated auxiliary roles of India according to their personal characteristics, specifically on how they read constraints. Before moving to the empirical analysis, we provide overarching definitions of the different master and auxiliary roles that are central to our empirical analysis of India as an emerging power. As defined earlier, the emerging power is the key master role because this role and its attached behavioural expectations are of revisionist essence. India has another master role as regional power that has been used as a springboard to conceive and play the emerging power master role. A regional power master role refers to a state with higher social and material capabilities than other states in a particular region. From this set of capacities that the state disposes, the behavioural expectation is that the regional power will tend to

\footnotetext{
${ }^{13}$ Italics added to note that Hermann here is referring to President Clinton, who shares a comparable profile.
} 
adopt special management responsibilities of that existing regional order. India also aspires to be a great power (non-achieved role). Great powers will adopt competitive strategies with other great powers and emerging states to prevent undermining their power and influence in the system as the state with highest social and material capabilities (see Thies and Nieman 2017: 31; see also Thies 2013: 45).

Since master roles gain meaning and direction also through auxiliary roles (Wehner 2015), India assumes a series of other roles in regional and international settings. Our discussion relates with these auxiliary roles; we elaborate on some here and Table 5 summarises others (which are mentioned later). First, a regional leader auxiliary role refers to the actual functions and set of duties that a government like India perceives for itself and that are attributed by other states in its relation to a particular region. The behavioural expectation is to adopt an active stand in providing regional public goods to the rest of the states and its own (Holsti 1970: 261). Second, India's regional protector or security provider role implies more issue specific leadership responsibilities of a state such as the provision of security and protection to the rest of the region or specific states within a regional setting (Holsti 1970). The behavioural expectation attached to the role of protector or security provider is that the state enacting this role will get involved directly or indirectly (aid in security issues) to make the counterpart safe. Role expectations are also about engagement to help preventing transnational crime with transborder consequences (Thies and Nieman 2017).

India has also two other auxiliary roles that focus on development. One is the internal developer role in which the government focuses on issues of domestic development. While the priority of this role is domestic, this does not preclude the state to play other roles internationally and is not necessarily associated with an isolated role behaviour (Holsti 1970: 269; Thies and Nieman 2017: 105). Like the internal developer, a developer role is issue-specific to matters of economic development, but there is an emphasis on a sense of obligation and duty to support and help other countries that are less developed than the one playing the developer role. The behavioural expectation is the creation and implementation of aid programmes and economic policies to support less developed states (see Holsti 1970: 266).

These master and auxiliary roles are key to understanding India's rising process and foreign policy behaviour under Vajpayee, Singh and Modi and how each enacts India's rising. Ganguly (2010) divides India's foreign policy into three periods: from independence to 1962; from 1962 to 1991 ; and from 1991 to the present day. In a recent work, Mohan (2015) adds a new phase that has started in 2014. Our discussion matches these episodic readings from Vajpayee's tenure onward in relation to the roles presented above. ${ }^{14}$ The identification of the types of roles of India has

\footnotetext{
${ }^{14}$ For a detailed explanation of the methodological steps and choices in the study and determination of India's roles, see Thies and Nieman (2017: 43-46). This work by Thies and Nieman (2017) is the most authoritative study of Indian foreign policy roles, and serves as an anchor to situate our discussion. They - as we do, too-rely on secondary sources to identify types of self-conceived identities and behavioural manifestations of these roles by India. Otherwise, in their analyses of foreign policy documents and utterances of political elites, Hansel and Möller (2015) find similar roles in India's foreign policy from the 2000s onwards.
} 
proven to be relatively consistent with other works on India's foreign policy (e.g. Friedrichs 2019; Ganguly 2018a, b; Gupta et al. 2019; Hansel and Möller 2015; Plagemann and Destradi 2019).

In the 1990s, Thies and Nieman (2017) identify a total of nine roles in India's foreign policy. Compared to the previous decade, they claim, some roles were no longer included in India's role set, while new ones were achieved in this decade. For instance, India did not possess the Soviet ally role as a consequence of the end of the Cold War. India found new auxiliary roles in the international system, such as internal developer-something that is seen as key by the political elite to locate a new master role as emerging power. Most importantly, India presented itself as a regional power, which underlined the country's development and growth well above its regional peers in terms of material capabilities. This shows India already achieved a master role of regional power in the 1990s, despite regional contestation by Pakistan (Ganguly 2018a, b). Moreover, India's transition from aspirant to actual nuclear power role was finally realised under Vajpayee. India tested nuclear weapons underground five times, indicating the achievement of nuclear power auxiliary role. Meanwhile, India started to show an interest in regional stability as it enacted the auxiliary role of regional protector and thus engaged in peacekeeping actions. Also, during Vajpayee's term, India actively participated in peacekeeping operations in Sierra Leone, Lebanon, and Burundi (Nambiar 2014).

There was a radical increase in India's number of roles into the 2000s with the role set composed of twenty-four roles (Thies and Nieman 2017: 110). After achieving its regional power master role, India used this to locate the emerging power master role reflective of its prioritisation of domestic (internal developer as auxiliary role) and burgeoning structural clout in terms of economic development growth. From this master role as emerging power India started to advance the role of great power-as an aspired and non-achieved master role. As the aspiration to and achievement of this new master role started to unfold, India's foreign policy behaviour appeared consistent with this intention of aspiring to a great power role and enacting an emerging power master role, which along with our interest in leaders constitutes the gist of this inquiry. For instance, to make sense of its rising power master role, India adopted the auxiliary roles of internal developer and nuclear power. Then, India began to promote certain normative understandings, and world and regional views by performing the auxiliary roles of liberal example and democracy promoter. These latter roles reflect the model of democracy and cultural background that India has adopted and sought to transmit in its foreign policy orientation. In the location of its master role as emerging power, India also adopted auxiliary roles that indicated its willingness to lead in its region and on the international stage. In this sense, the roles of regional leader, balancer, protector, and bridgebuilder showed India's proactive social life as a foreign policy actor. This expansion of its role set arguably points to a remaking of India's foreign policy constraints.

India's many foreign policy roles into the new millennium are in line with research that highlights India's proactive foreign policy towards great powers, neighbouring states, and the wider South Asian region (Mohan 2015), and make the Indian prime ministers all the more relevant. Indeed, these roles only concern one side of our argument, but not the full picture vis-à-vis the relationship between 
roles and leaders. In this sense, the scores provided by LTA reveal some interesting features that help make better sense of the different roles and actions of the three prime ministers under study when it comes to foreign policy-making at the national level, as well as India's actions towards both its region and the international system. Now, we shall discuss how the three Indian leaders influenced its foreign policy in the context of India's rising.

\section{Vajpayee}

Vajpayee's scores indicate that he would challenge constraints in an indirect manner, while he would focus on eliminating potential threats and problems and see the world in an 'us-versus-them' manner (Hermann 2003). Vajpayee is more relationship-focused than problem-solving-oriented; his scores indicate that he would have a directive leadership style. These scores are consistent with some of the key features of Vajpayee's actual foreign policy. For example, he empowered his foreign ministers and national security advisor (in-group bias and relationship-focused) to articulate and implement a foreign policy that would raise India's international profile per the country's increasing economic clout (Malone et al. 2015). Moreover, his propensity for challenging constraints indirectly corresponded with his nuclear policy. In fact, it is under Vajpayee's leadership that India, as noted, tested its nuclear capabilities underground five times. While some may argue that testing one's nuclear capabilities is a direct challenge to constraints, Vajpayee's rhetoric highlighted the fact that India was rather reacting and following the cues of a hostile surrounding environment (while also stating its commitment to cooperating with the US). In a letter to the US president to explain these tests, Vajpayee stated the following:

I have been deeply concerned at the deteriorating security environment, specifically the nuclear environment, faced by India for some years past. We have an overt nuclear weapon state on our borders, a state which committed armed aggression against India in 1962. Although our relations with that country have improved in the last decade or so, an atmosphere of distrust persists mainly due to the unresolved border problem. (Vajpayee 1998)

India's acquisition of nuclear power status implied that locating the nuclear power role is related to a leadership type that seeks to eliminate potential threats-nuclear weapons were seen as a deterrence mechanism and a way to keep peace in the region (Joseph 1998). At the same time, Vajpayee's directive leadership style is consistent with India's enactment of a regional power role as master role, as well as of associated auxiliary roles such as regional leader, internal developer, developer, and emerging power. Vajpayee's foreign policy was to increase economic interdependence (developer and internal developer roles) with regional peers by concluding negotiations for a South Asian Free Trade Agreement (SAFTA) in 2004. While advancing economic integration, the political goal of engaging Pakistan in cooperative (trade) mechanisms also served the purpose of locating a leadership role. In fact, Vajpayee was key to containing the nationalistic views within his own political party with regard to 
Pakistan and its near-neighbourhood policy as well as to advancing a pragmatic 'good neighbour' policy (Malone et al. 2015). All are suggestive of indirect or otherwise cautious attempts to overcome previous constraints on India's foreign policy.

As Mohan (2015: 138) stresses, this policy is not based on idealism but on the view that regional peace and cooperation were essential to achieving and exerting a larger global role, and to being accepted by other powers on the world stage. Thus, Vajpayee's LTA scores show interesting features of India which has advanced new roles in its foreign policy, such as emerging power and aspirant great power. It was under Vajpayee that India started to construct the emerging power role and shows its intentions of achieving a great power role as part of its foreign policy goals. In this process of advancing new roles, Vajpayee sought to reassert the country's master role as regional power. Playing an active regional power role was seen as an indispensable condition for demonstrating India's credentials as a would-be world power. In other words, Vajpayee's directive leadership is consistent with the conceptions and performances of India's master roles and auxiliary roles, including the aspired-to ones. These roles show the Indian leader's foreign policy goals and strategy of enhancing their state's reputation within and beyond its own region. India under Vajpayee seems to have renewed and reset the milestones for becoming a great power, and cautiously punched above its structural weight to challenge constraints on its place in world politics. These challenges to constraints are rather advanced in a cautious and indirect way reflecting the two traits of the leader when playing the role of emerging power.

Thus, Vajpayee saw constraints as something that can be overcome and does not limit the potential emergence of India in its region and in the international system. However, the way he challenged the existing constraints was rather indirect and consistent with a directive leadership style. For instance, he empowered his cabinet to seek achieving rapid economic growth (internal developer auxiliary role). The internal developer role was prioritised for the purpose of cementing the emerging power master role and constructing a new platform to advance the aspired great power role. Moreover, Vajpayee conceived and located the auxiliary role as developer for India since one of the key goals was India as a driving force in its region to increase economic interdependence. Vajpayee went further to amplify the benefits of economic interdependence through the developer role and played the role of leader to establish a formal umbrella institution, the SAFTA, to facilitate and increase trade. This move aimed at creating trade links with Pakistan that would increase costs of confrontation especially when India adopted a nuclear power role to match and deter Pakistan's nuclear capacity. Vajpayee's traits show that he challenged constraints indirectly by looking at the US to reassure the system that his nuclear auxiliary role was a reaction to Pakistan's first moves in this issue-area and to prove that India could act as a responsible emerging power and cooperate with the US on this matter. India's role-based foreign policy actions under Vajpayee's leadership were with the purpose of further increasing the salience of its emerging power master role. 


\section{Singh}

As mentioned earlier, compared to Vajpayee and Modi, Singh deviates the most from the world leaders' average scores. Singh's traits suggest he would either respect or challenge constraints when necessary depending on the context he faced. Moreover, he would be more inclined to deal with threats and have a relationship focus as elements of his foreign policy. His profile points in the direction that he would be open to new information. Thus, Singh's traits would translate into a directive (constraints challenger) or collegial (constraints respecter) leadership style.

India's main priority is to increase its material capacity through economic growth and to start to locate its self-conceived (non-achieved) great power role internationally. According to Rej, 'Since the beginning of the economic reforms in India in 1991 [...] the primary task of India's security and foreign policy has been to create an external atmosphere for the country that is conducive to India's economic growth' (Rej 2017: 146). As this scholar notes, Singh argued that this 'has directed India's strategic conduct as well as external relations' (ibid.). During Singh's tenure, most of the new roles started to achieve a degree of stability as part of India's role set (Thies and Nieman 2017). India exerted a leadership role in its neighbourhood policy and sought to increase economic cooperation with Pakistan, simultaneously striving to bring the security dimension of the two countries' relationship into the fold and to solve the Kashmir issue via diplomatic channels (Mohan 2015). As a nuclear power, India's leadership kept pushing the boundaries of its foreign policy challenges.

India started to perform the active auxiliary roles of leader and security protector to cope with emerging security threats, such as piracy in the Indian Ocean. The security provider or protector role was also seen as a way to consciously play the developer role at the regional level too. For instance, India patrolled the Maldives' and Mauritius's exclusive economic zones to fight piracy and create cooperation mechanisms on this matter with Sri Lanka. Further, the India-ASEAN Free Trade Agreement (implemented in 2010) increased the country's need to secure the flow of trade into this region by enacting a security provider role (Scott 2015: 473-75). In fact, Singh had a directive leadership style taking form in the foreign policy goal of securing India's South Asian primacy. However, this leadership fits with his collegial leadership style, as the realisation of the South Asian primacy project was achieved through the provision of cooperative leadership in that region. Singh's directive and collegial leadership styles are consistent with India's role performances in this region as an Asian regional power, developer, and regional protector. These are a series of roles that underpin the emerging power role, but the aspiration to achieve a great power master role is central.

The relationship with the US developed further under Singh, in the sense that cooperation therewith became the cornerstone of India's foreign policy. The US started to altercast India into a balancer role against China in the Southeast Asia region. While India perceived this relationship to go beyond strategic containment of China, it accepted rather reluctantly the balancer role-as in its role set 'Chinese rival' is an active role. In the nuclear policy issue-area, the US and India showed an increasing pattern of cooperation. As part of the agreement reached in 2005, the 
US offered fuel and technical support for India's civilian nuclear programme once it had separated it out from military programmes, allowed for the inspection of its nuclear plants, secured related technology and fuels, and continued its moratorium on nuclear testing. The making of this deal is attributed to the leaders of both countries at the time (Kapur 2010; Kirk 2010; Tellis 2015). This agreement showed the US legitimation of India as holder of the nuclear power auxiliary role, as well as of the latter's growing international stature (Kapur 2010). The nuclear deal was seen as of paramount importance to India's new international status. Here, we find how Singh alternated between constraints challenger and respecter: Indian foreign policy during his tenure both sought to enhance its status in regional, world politics and seek consensus on difficult issues. Put differently, Singh successfully negotiated constraints or roles as devised by the hegemon in the international system.

During Singh's tenure, India sought a permanent seat at the UNSC-joining forces with Brazil, Japan, and Germany (the G-4) to that end. Chitalkar and Malone (2015: 586) emphasise that India's claim to a permanent seat was based on a sense of entitlement given its rising status; while the G-4 members also highlighted their weight in international relations, their overall burden of financial costs regarding the UN, and their contribution to global peacekeeping. Despite Singh's desire to secure a permanent seat, his messages did not bring the expected change in the UNSC. Yet, India received Obama's support for a permanent seat in 2010, at a time when the UN reform debate was at a stalemate. This initiative corresponds with the pursuit of 'a fairer representation' in international politics, as we discussed earlier, which Singh aspired to in a collegial style with others' support. It likewise shows Singh's directive leadership type for seeking 'acceptance by others by engaging in actions on the world stage that enhance the state's reputation' (Hermann 2003). In other words, Singh seems to rely on both leadership styles to play different roles in making sense of India's rising process. In fact, India under Singh seems to have matched the structural conditions of rising to expand the country's influence in its near and far neighbourhoods, as well as to be recognised as an actor of international stature. India in this period became a good match between its leader's profile and the international actions of the country.

Singh perceived constraints can be challenged if deemed necessary to achieve foreign policy goals, yet depending on the context also respected them not to break with strategic partners and not to increase the risks of the existing threats. For instance, Singh adopted a constraints challenger approach to Pakistan to change the enemydriven relationship. He sought to increase economic bonds and act as a leader to find diplomatic solutions to the Kashmir problem. Singh pursued an active approach towards Pakistan to locate and make sense of India's regional power role and show its willingness to the audience of regional states about its commitment to regional peace and to the provision of public security goods. The emerging power master role was also played along with the regional power master role as India started to manage the existing regional order in both security and trade issues. Concurrently, other auxiliary roles also underpinned the emerging power and regional power master roles. Singh brought further the developer role as he tried to increase the economic bonds with Pakistan, deepen the SAFTA, and create a new way to promote trade throughout the India-ASEAN Free Trade Agreement. Singh also challenged constraints to 
enact India's security provider auxiliary role and expand its security duties in the Indian Ocean. Yet, he also showed his capacity to follow and respect constraints here as he also made sure to have the support and consent of neighbouring states (for example, Maldives and Mauritius) that legitimated and attributed both its security provider and regional leader auxiliary roles. These roles were also functional to its developer role in the Asian region.

Finally, pursuing India's claim to a permanent seat in the UNSC, Singh pushed its relationship with the US to be recognised as a great power. Yet, Singh oscillated between challenging and respecting constraints in the UNSC venture. First, he articulated with other emerging states the need for reforming the UNSC to fit India's new perceived status (challenging constraints), but he advanced India's demands in a rather collegial and consensus-seeking way (respecting constraints). At the same time, Singh turned to the US to validate and legitimate its claims for a permanent seat at the UNSC; something still not achieved for India and other emerging powers. Thus, as much as Singh could challenge constraints, he could also pursue consensus-based approaches when deemed necessary; these both displayed in the role selection process and how India's role set of master and auxiliary roles were played during Singh's term in office.

\section{Modi}

Finally, as presented earlier, Modi's traits scores are close to the world leaders' averages; his profile is the most challenging too. However, Modi's distrust of others is one standard deviation lower than the world leaders' average. The scores make the interpretation of Modi's profile difficult, with no eventual clear-cut correlations between his personality traits and India's foreign policy role-based behaviour able to be established with certainty. Modi's scores are within the control group of world leaders. His low score on distrust of others and his low-leaning in-group bias may suggest that Modi tends to see the world as a nonthreatening place in which conflicts are dealt with on a case-by-case basis. This interpretation also implies that such a leader would recognise constraints as situations emerge while looking for possibilities of cooperation with others in the international arena (Hermann 2003: 200).

Modi did not show much interest in foreign policy matters during his electoral campaign; once in power he became very proactive in visiting other countries: a total of fifty-three, indeed, between 2015 and 2018. Yet, he has not been able to transform India's foreign policy, despite his efforts and goals to improve relations with China and Pakistan, remove all signs of role residual behaviour from the country's past nonaligned role, and expand its influence in the South Asian region (Ganguly 2017, 2018a, b). For instance, Modi decided not to attend the Non-Aligned Movement's meeting in September 2016, '[both] ending the rhetorical references to nonalignment and expressing an unwillingness to support its existing institutional structure' (Ganguly 2017: 138), while he has also pursued a more pragmatic approach to India's relationship with the US.

In fact, Modi has followed the foreign policy pillars established and strategies advanced by his two predecessors (Bashur 2017). Ganguly's (2017) conclusion that 
Modi has 'not constituted a fundamental break from India's past policies' may correspond to the fact that we observe here a contextual leadership style. While Modi has adopted a more personalised approach to foreign policy consistent with his populist project, his populism seems to have not undermined the direction and the way the emerging power master role was played at least in his first period in office. His foreign policy is not more assertive than the other leaders' nor is it more passive or reactive. Plagemann and Destradi (2019) conclude that Modi as a populist foreign policy actor has not made most of the structural capacity of India and his personalisation in the foreign policy making has not meant changes in the rising power or emerging power master role. Rising power master role seems to be played with some impact capacity from the leader figure as such which are consistent with the results of neither being a constraint respecter or constraint challenger.

During Modi's first term, we observe a rather contextually informed leader. India played the emerging power master role with Modi's interpretations, but without substantial changes brought by his agency. For example, Modi challenged constraints in India's relationship with Pakistan, yet simultaneously adopted a more cautious, context-based approach to it. Modi played the leader auxiliary role to always keep a door open to dialogue with Pakistan even when criticised domestically for doing this when tensions between the two countries increased. Modi dealt with Pakistan on a case-by-case basis as he focused on immediate challenges such as the threat of terrorism but excluded the long-standing and sensitive issue of Kashmir from the bilateral agenda (Bajpai 2017). Likewise, Modi as a constraints respecter was also cautious: his dealing with the US role demands and altercasting of India as being the balancer of China illustrate this. Instead of taking the role as the US expected, Modi adopted a casting of alliances with the US, Japan, and Australia to enact the auxiliary role of balancer to China on a case-by-case basis. Under this alliance system, the balancer role was not exclusive of India and it became context-based and kept the door open to future cooperation with China as they do within the BRICS institution. In fact, India's relationship with China can be described as one with different layers of competition and cooperation (Bajpai 2017).

This interpretation of how Modi's personal characteristics shaped the emerging power master role during his first term in office is admittedly somewhat restricted. This notwithstanding, as Ganguly hints at, studying the political personality of Modi in years to come is still important. He argues that 'Modi has adopted a more centralised form of decision-making' (Ganguly 2017: 142). This 'personality-dependent policymaking style' will likely require further studies of Modi, his traits, worldview, and leadership style. It is plausible to expect that, in his second term in office, Modi will exhibit his personality traits more distinctly.

\section{Conclusion}

This article is a first step to advance the correspondence between the structural conditions of rising powers and their leaders' personality to make sense of or capitalise on that emergence process. It makes the case for paying more attention to how leaders' personality traits function as key variables in a context of rising. Rising powers 
are not all about structural material conditions, or ideational ones-in which the state is the unit of analysis. Rising powers as a process are also about how leaders read the settings at hand, by accepting or challenging the existing constraints.

In an ambitious and challenging undertaking, our article used role theory to conceptualise the status dimension and subsidiary functions-that is, master and auxiliary roles, and then matched these with leadership traits. Emerging power as master role reflects the growing economic, material, and social capabilities of the state within the regional and international orders.

We observe through the case of India under the tenures of prime ministers Vajpayee, Singh and Modi that they dropped altogether the nonaligned role from the country's role set and started to reassert the master role as emerging power, as a springboard to great power status. This role change and reasserting its master role brought India to perform a series of auxiliary roles within the South Asia region that were appropriate for expanding its influence in both economic and security affairs. Moreover, as India grew into its new stature as bestowed by its economic clout and achieved role as emerging power, Vajpayee and Singh actively pursued a strategy of being accepted as a nuclear power. Especially under Singh, corresponding to his high need for power trait, India received the validation of its nuclear power role from the US as the ordering state within the international system. India advanced its goals of being diplomatically proactive in multilateral settings such as the G20, BRICS, and the UN with the purpose of receiving recognition not only as an emergent but also as a great power.

While systemic and relational features are important in understanding the choices and priorities in emerging powers' foreign policies, we can observe that India's leaders reacted differently to the social setting that they faced during their respective terms. The three prime ministers analysed here exhibit leadership traits and styles that account for how India would advance its foreign policy roles, as well as for the different role conceptions and variations in the role performances of both master and auxiliary roles. While Vajpayee possessed a directive type of leadership and challenged constraints in an indirect way, as his casting of India's nuclear power role shows, Singh demonstrated directive or collegial leadership styles-because he both challenged and respected constraints. Vajpayee and Singh have to be seen as the individuals who redesigned India's foreign policy within a new international setting (post-Cold War) and promoted new state roles in a context of economic growth and a more liberal-oriented model of development.

Both types of leadership and how these two prime ministers would challenge constraints seem to have been key for India's role actions and its recognition as having a new international status. With Vajpayee and Singh, India seems to have punched above its weight on the international scene-although some outcomes were not the expected ones, as the case of a permanent seat at the UNSC illustrates. With Modi, meanwhile, it is difficult draw hard conclusions, as his traits fall within the parameters of the LTA control group's average scores. Nevertheless, some of Modi's traits indicate that his leadership style is contextually dependent, suggesting that he responds to the demands of the regional and international situation rather than contributing to role demands for concrete action. Modi, in fact, has not yet altered India's foreign policy role behaviour but has introduced his own interpretations 
to auxiliary roles to make sense of regional and international contexts such as the leader and balancer roles, respectively. Instead, during his first term, he followed the course set by others, being unable to add his own tweaks to Indian foreign policy master roles such as regional, emerging, and even aspirant to great power (Bashur 2017; Ganguly 2017). Thus, it seems to be the case that Modi's influence on India's state roles is more limited than his immediate predecessors, and as such the country is not making the most of its master role as emerging power.

As preliminary concluding remarks, our discussion of India's leaders, roles, and foreign policy shows that personality traits are important to understanding the phenomenon of emergence in world politics. This article presents a promising start to a reorientation of studying emerging powers' leadership. We observed that scores across the three leaders differed, the variance in their type of leadership and how they challenge or not presenting constraints help us understand why India sometimes shows nuances and differences in how it advances its rising project. This is pertinent when taking into consideration its master roles as emerging power, as an achieved role, and great power, as a still-aspired-to one. The leaders' personality types and approach to constraints also tell us how India constructs, develops, and performs auxiliary roles to make sense of conditions of rising in both regional and international affairs. Our discussion illustrates that an individual-level analysis of foreign policy roles allows a meaningful reading and contextualisation of India's rising.

Whereas we stressed the significance of individual level to studying BRICS and emerging powers, this focus does not dismiss the importance of the other levels of analysis in rising powers' foreign policy. The interplay of leaders' traits and rolesas expressions of both material and social dimensions, as well as of self-conceptions and other expectations-helped assess how leaders make sense of their country's conditions of rising within both the regional and international systems. Leaders' traits and their responsiveness to constraints were key elements in providing a thorough understanding of why some emerging powers across different time periods during their rising process seem to push above or below their weight. A compelling reason, as this article showed, is that leaders of rising powers interpret these constraints and decide on a course of action that they will thereafter pursue. It is, hence, essential to understand political leadership of emerging powers, specifically by conducting case studies that would trace changing foreign policy agendas-with particular attention paid to those at the helm.

\section{References}

Alexandroff, Alan and Andrew Cooper, eds (2010) Rising States, Rising Institutions: Challenges for Global Governance, Baltimore: Brookings Institution Press.

Bajpai, Kanti (2017) 'Narendra Modi’s Pakistan and China policy: assertive bilateral diplomacy, active coalition diplomacy', International Affairs 93(1): 69-91.

Bashur, Rajesh (2017) 'Modi’s foreign policy fundamentals: a trajectory unchanged', International Affairs 93(1): 7-26.

Blarel, Nicolas and Hannes Ebert (2015) 'Explaining the evolution of contestation in South Asia', International Politics 52(2): 223-38. 
Breuning, Marijke (2011) 'Role theory research in international relations: state of the art and blind spots', in S. Harnisch, C. Frank and H. Maull, eds, Role Theory in International Relations: Approaches and Analyses, 16-35, Abingdon: Routledge.

Breuning, Marijke and Anna Pechenina (2020) 'Role Dissonance in Foreign Policy: Russia, Power, and Intercountry Adoption', Foreign Policy Analysis 16(1): 21-40.

Brummer, Klaus, Michael Young and Ozgur Ozdamar et al. (2020) 'Forum: Coding in Tongues: Developing Non-English Coding Schemes for Leadership Profiling', International Studies Review 22(4): 1039-67.

Cantir, Cristian and Juliet Kaarbo (2012) 'Contested Roles and Domestic Politics: Reflections on Role Theory in Foreign Policy Analysis and IR Theory', Foreign Policy Analysis 8(1): 5-24.

Cason, Jeffrey and Timothy Power (2009) 'Presidentialization, Pluralization, and the Rollback of Itamaraty: Explaining Change in Brazilian Foreign Policy Making in the Cardoso-Lula Era.' International Political Science Review 30(2): 117-40.

Chitalkar, Poorvi and David Malone (2015) 'India and Global Governance', in D. Malone, R. Mohan, and S. Raghavan, eds, Oxford handbook of Indian foreign policy, Oxford: Oxford University Press. DOI: https://doi.org/10.1093/oxfordhb/9780198743538.013.42.

Cooper, Andrew (2016) BRICS: A Very Short Introduction, Oxford: Oxford University Press.

Cuhadar, Ç. Esra, Juliet Kaarbo, Barış Kesgin, and Binnur Ozkececi-Taner (2021) 'Turkish leaders and their foreign policy decision-making style: a comparative and multi-method perspective', Turkish Studies 22(1): 1-27.

Cuhadar, Ç. Esra, Juliet Kaarbo, Barış Kesgin and Binnur Ozkececi-Taner (2017a) 'Personality or Role? Comparisons of Turkish Leaders across Different Institutional Positions', Political Psychology 38(1): 39-54.

Cuhadar, Ç. Esra, Juliet Kaarbo, Barış Kesgin, and Binnur Ozkececi-Taner (2017b) 'Examining Leaders' Orientations to Structural Constraints: Turkey's 1991 and 2003 Iraqi War Decisions', Journal of International Relations and Development 20(1): 29-54.

de Sá Guimarães, Feliciano and Martin Maitino (2017) 'Socializing Brazil into Regional Leadership: The 2006 Bolivian Gas Crisis and the Role of Small Powers in Promoting Master Roles Transitions', Foreign Policy Analysis DOI: https://doi.org/10.1093/fpa/orx010.

Destradi, Sandra (2012) 'India as a democracy promoter? New Delhi's involvement in Nepal's return to democracy', Democratization 19(2): 286-311.

Destradi, Sandra (2017) 'Reluctance in international politics: A conceptualization', European Journal of International Relations 23(2): 315-40.

Dyson, Stephen (2006) 'Personality and foreign policy: Tony Blair's Iraq decisions', Foreign Policy Analysis 2(3): 289-306.

Ebert, Hannes and Daniel Flemes, eds (2018) Regional Powers and Contested Leadership, Palgrave Macmillan.

Friedrichs, Gordon (2019) 'From factions to fractions: India's foreign policy roles across different party systems', India Review 18(2): 125-60.

Ganguly, Sumit (2010) 'The Genesis of Nonaligment', in S. Ganguly, ed., India's foreign policy: Retrospect and prospect, 1-10, New Delhi: Oxford University Press.

Ganguly, Sumit (2017) 'Has Modi Truly Changed India's Foreign Policy?', Washington Quarterly 40(2): $131-43$.

Ganguly, Sumit (2018) 'India as a Regional Power: Opportunities and Constraints', in H. Ebert and D. Flemes, eds, Regional Powers and Contested Leadership, 231-46, Palgrave Macmillan.

Ganguly, Sumit (2018) 'Modi's Foreign Policy Revolution? In India, Radical Change Is Hard to Come By', Foreign Affairs, available at https://www.foreignaffairs.com/articles/india/2018-03-08/modisforeign-policy-revolution (last accessed on 13 March, 2019).

Goffman, Erving (1971) Relations in Public: Microstudies of the Public Order, Middlesex: Penguin Books.

Guha, Ramachandra (2010) 'Political Leadership', in N. G. Jayal and P. B. Mehta, eds, Oxford Companion to Politics in India, 288-98, Oxford University Press.

Gupta, Surupa, Rani D. Mullen, Rajesh Basrur, Ian Hall, Nicolas Blarel, Manjeet S. Pardesi and Sumit Ganguly (2019) 'Indian Foreign Policy under Modi: A New Brand or Just Repackaging?', International Studies Perspectives 20(1): 1-45.

Hagan, Joe (1994) 'Domestic Political Systems and War Proneness', Mershon International Studies Review 38: 183-207. 
Hansel, Mischa and Miriam Möller (2015) 'Indian Foreign Policy: A Role-Theoretical Analysis', Asian Politics \& Policy 7(1): 79-104.

Harnisch, Sebastian (2011) 'Role Theory: Operationalization of Key Concepts', in S. Harnisch, C. Frank and H. Maull, eds, Role Theory in International Relations: Approaches and Analyses, 7-15, Abingdon: Routledge.

He, Kai and Huiyun Feng (2015) 'Transcending rationalism and constructivism: Chinese leaders' operational codes, socialization processes, and multilateralism after the Cold War', European Political Science Review 7(3): 401-26.

Hermann, Margaret (1987) 'Assessing the foreign policy orientations of Sub-Saharan African Leaders', in S. G. Walker, ed., Role theory and foreign policy analysis, 161-98, Durham: Duke University Press.

Hermann, Margaret (2003) 'Assessing Leadership Style: Trait Analysis', in J. M. Post, ed., The psychological assessment of political leaders: with profiles of Saddam Hussein and Bill Clinton, 178-212, Ann Arbor: University of Michigan Press.

Hollis, Martin and Steve Smith (1986) 'Roles and Reasons in Foreign Policy Decision Making', British Journal of Political Science 16(3): 269-86.

Holsti, Kalevi (1970) 'National Role Conceptions in the Study of Foreign Policy', International Studies Quarterly 14(3): 233-309.

Hurrell, Andrew (2008) On Global Order: Power, Values and the Constitution of International Society, Oxford: Oxford University Press.

Joseph, Mallika (1998) 'BJP Manifesto: On Nation's Security and Foreign Policy', Institute of Peace and Conflict Studies India, available at http://www.bu.edu/globalbeat/pubs/mallika022898.html (last accessed on 11 March, 2019).

Kapur, S. Paul (2010) 'India and the United States from World War II to the Present: A Relationship Transformed', in S. Ganguly, ed., India's foreign policy: Retrospect and prospect, 251-74, New Delhi: Oxford University Press.

Keller, Jonathan (2005) 'Constraint Respecters, Constraint Challengers, and Crisis Decision Making in Democracies: A Case Study Analysis of Kennedy versus Reagan', Political Psychology 26(6): 835-67.

Kesgin, Barış (2020) 'Features of Foreign Policy Birds: Israel's Prime Ministers as Hawks and Doves', Cooperation and Conflict 55(1): 107-26.

Kesgin, Barış (2019) 'Uncharacteristic Foreign Policy Behavior: Sharon's Decision to Withdraw from Gaza', International Area Studies Review 22(1): 76-92.

Kille, Kent and Roger Scully (2003) 'Executive Heads and the Role of Intergovernmental Organizations: Expansionist Leadership in the United Nations and the European Union', Political Psychology 24(1): 175-98.

Kirk, Jason (2010) 'The Evolution of India's Nuclear Policies', in S. Ganguly, ed., India's foreign policy: Retrospect and prospect, 275-300, New Delhi: Oxford University Press.

Larson, Deborah (2018) 'New Perspectives on Rising Powers and Global Governance: Status and Clubs', International Studies Review 20(2): 247-54.

Larson, Deborah and Alexei Shevchenko (2014) 'Managing Rising Powers: The Role of Status Concerns', in T. V. Paul, D. Larson and W. Wohlforth, eds, Status in World Politics, 33-57, Cambridge: Cambridge University Press.

Lemke, Douglas (2010) 'Dimensions of Hard Power: Regional Leadership and Material Capabilities', in D. Flemes, ed., Regional Leadership in the Global System: Ideas, Interests and Strategies of Regional Powers, 31-50, Aldershot: Ashgate.

Levine, Nick and Michael Young (2014) 'Leadership Trait Analysis and Threat Assessment with Profiler Plus', Proceedings of ILC 2014 on $8^{\text {th }}$ International Lisp Conference, Montreal, QC, Canada, 14-17 August, 2014, Association for Computing Machinery.

Malone, David, C. Raja Mohan and Srinath Raghavan (2015) 'India and the World', in D. Malone, R. Mohan and S. Raghavan, eds, Oxford handbook of Indian foreign policy, Oxford: Oxford University Press. DOI: https://doi.org/10.1093/oxfordhb/9780198743538.013.1.

Marsh, Kevin and Christopher Jones (2017) 'Breaking Miles' Law: The Curious Case of Hillary Clinton the Hawk', Foreign Policy Analysis 13(3): 541-60.

McCourt, David (2014) Britain and World Power since 1945. Constructing a Nation's Role in International Politics, Ann Arbor: University of Michigan Press.

Mearsheimer, John (2014) The Tragedy of Great Power Politics, New York and London: W.W. Norton. 
Mitchell, David (2007) 'Determining Indian Foreign Policy: An Examination of Prime Ministerial Leadership Styles', India Review 6(4): 251-87.

Mohan, C. Raja (2015) 'Foreign Policy after 1990: Transformation through Incremental Adaptation', in D. Malone, R. Mohan and S. Raghavan, eds, Oxford handbook of Indian foreign policy, Oxford: Oxford University Press. DOI: https://doi.org/10.1093/oxfordhb/9780198743538.013.10.

Nambiar, Satish (2014) 'India and United Nations Peacekeeping Operations. Ministry of External Affairs, Government of India', available at https://mea.gov.in/articles-in-indian-media.htm?dt1/22776/India+ and+United+Nations+Peacekeeping+Operations (last accessed on $10 \mathrm{March}, 2019$ ).

Narlikar, Amrita and Aruna Narlikar (2014) Bargaining with a Rising India: Lessons from the Mahabharata, Oxford: Oxford University Press.

Organski, A. F. K. and Jacek Kugler (1980) The War Ledger, Chicago: The University of Chicago Press.

Paul, T. V. (ed.) (2016) 'Accommodating Rising Powers: Past, Present, and Future', Cambridge: Cambridge University Press.

Paul, T. V. and Manesh Shankar (2014) 'Status Accommodation through Institutional Means: India's Rise and the Global Order', in T. V. Paul, D. Larson, W. Wohlforth, eds, Status in World Politics, 165-91, Cambridge: Cambridge University Press.

Plagemann, Johannes and Sandra Destradi (2015) 'Soft Sovereignty, Rising Powers and Subnational Foreign Policy-Making: The Case of India', Globalizations 12(5): 728-43.

Plagemann, Johannes and Sandra Destradi (2019) 'Populism and Foreign Policy: The Case of India', Foreign Policy Analysis 15(2): 283-301.

Post, Jerrold, ed. (2003) The psychological assessment of political leaders: with profiles of Saddam Hussein and Bill Clinton, Ann Arbor: University of Michigan Press.

Rej, Abhijnan (2017) 'Beyond India's Quest for a Neoliberal Order', Washington Quarterly 40(2): 145-61.

Schafer, Mark and Stephen G. Walker. (2006) 'Democratic Leaders and the Democratic Peace: The Operational Codes of Tony Blair and Bill Clinton', International Studies Quarterly 50(3): 561-83.

Scott, David (2015) 'The Indian Ocean as India's Ocean', in D. Malone, R. Mohan and S. Raghavan, eds, Oxford handbook of Indian foreign policy, Oxford: Oxford University Press. DOI: https://doi.org/10. 1093/oxfordhb/9780198743538.013.34.

Sinha, Aseema (2016) 'Partial accommodation without conflict: India as a rising link power', in T. V. Paul, ed., Accommodating Rising Powers. Past, Present and Future, 222-45, Cambridge: Cambridge University Press.

Stuenkel, Oliver (2016) Post-Western World: How Emerging Powers Are Remaking Global Order, Cambridge: Polity Press.

Tellis, Ashley (2015) 'US-India relations: The Struggle for an Enduring Partnership', in D. Malone, R. Mohan and S. Raghavan, eds, Oxford handbook of Indian foreign policy, Oxford: Oxford University Press. DOI: https://doi.org/10.1093/oxfordhb/9780198743538.013.35.

Thies, Cameron (2013) The United States, Israel, and the Search for International Order: Socializing States, New York: Routledge.

Thies, Cameron (2012) 'International Socialization Processes vs. Israeli National Role Conceptions: Can Role Theory Integrate IR Theory and Foreign Policy Analysis?', Foreign Policy Analysis 8(1): 25-46.

Thies, Cameron (2010) 'Role Theory and Foreign Policy', in R. Denemark, ed., The International Studies Encyclopedia. Blackwell Reference Online, available at http://www.isacompendium.com (last accessed on 23 June, 2010).

Thies, Cameron and Mark Nieman (2017) Rising Powers and Foreign Policy Revisionism, Ann Harbor: University of Michigan Press.

Vajpayee, Atal B. (1998) Nuclear Anxiety; Indian's Letter to Clinton On the Nuclear Testing, available at https://www.nytimes.com/1998/05/13/world/nuclear-anxiety-indian-s-letter-to-clinton-on-the-nucle ar-testing.html (last accessed on 12 March, 2019).

van der Westhuizen, Janis (2016) 'South Africa's soft power conundrum: how to win friends and influence people in Africa', Journal of Political Power 9(3): 449-65.

Volgy, Thomas, Renato Corbetta, Keith Grant and Ryan Baird, eds (2011) 'Major Powers and the Quest for Status in International Politics: Global and Regional Perspectives', New York: Palgrave Macmillan.

Walker, Stephen (1987) 'Introduction: The Relevance of Role Theory to Foreign Policy Analysis', in Stephen Walker, ed., Role Theory and Foreign Policy Analysis, 1-4, Durham: Duke University Press. 
Walker, Stephen G. (1979) 'National Role Conceptions and Systemic Outcomes', in Lawrence Falkowski, ed., Psychological Models in International Politics, 169-210, Boulder: Westview Press.

Walker, Stephen, Mark Schafer and John Beieler (2016) 'Belief Systems and Foreign Policy Roles: Role Contestation in U.S. Foreign Policy Decisions', in J. Kaarbo and C. Cantir, eds, Domestic Role Contestation, Foreign Policy, and International Relations, 122-39, New York: Routledge.

Wehner, Leslie (2017) 'Emerging Powers in Foreign Policy', Oxford Research Encyclopedia of Politics, 24 May, available at https://oxfordre.com/politics/view/https://doi.org/10.1093/acrefore/9780190228 637.001.0001/acrefore-9780190228637-e-363 (last accessed on 19 May, 2021).

Wehner, Leslie (2015) 'Role expectations as foreign policy: South American secondary powers' expectations of Brazil as a regional power', Foreign Policy Analysis 11(4): 435-55.

Wehner, Leslie and Cameron Thies (2014) 'Role Theory, Narratives, and Interpretation: The Domestic Contestation of Roles', International Studies Review 16(3): 411-36.

Wehner, Leslie and Cameron Thies (2021) 'Leader Influence in Role Selection Choices: Fulfilling Role Theory's Potential for Foreign Policy Analysis', International Studies Review, online first 14 April, https://doi.org/10.1093/isr/viab014.

Windsor, Leah, James Cupit and Alistair Windsor (2019) 'Automated content analysis across six languages', PLOS ONE 14(1): e0224425.

Publisher's Note Springer Nature remains neutral with regard to jurisdictional claims in published maps and institutional affiliations.

Barış Kesgin is Associate Professor of Political Science \& Policy Studies at Elon University (North Carolina, USA). He specialises in foreign policy analysis and political leadership - more specifically, of Israel and Turkey. His most recent research appeared in Cooperation and Conflict, International Area Studies Review, Political Psychology, and Turkish Studies.

Leslie E. Wehner is Reader (Associate Professor) in International Relations at the University of Bath, UK. His research interests include social constructivism and role theory in international relations and foreign policy analysis. He also conducts research on emerging powers (BRICS), populism in IR and regional cooperation and trade strategies of Latin American states. His most recent articles have been published in Cambridge Review of International Affairs, Foreign Policy Analysis, International Studies Review, International Politics, International Relations, and Journal of International Relations and Development. 